\title{
МЕТОДОЛОГІЧНІ ПРИНЦИПИ УКЛАДАННЯ ГАЛУЗЕВОГО ТЕРМІНОЛОГІЧНОГО СЛОВНИКА
}

\author{
ТЕТЯНА ПЕТРОВА \\ Харківський національний аграрний університет ім. В. В. Докучаєва, \\ Харків - Україна \\ t-petrova@ukr.net; ORCID: 0000-0002-9534-9891 \\ METODOLOGICZNE ZASADY OPRACOWANIA \\ SŁOWNIKA TERMINOLOGICZNEGO DANEJ DZIEDZINY \\ TETIANA PETROWA \\ Charkowski Narodowy Uniwersytet Rolniczy imienia W. W. Dokuczajewa, \\ Charków - Ukraina
}

STRESZCZENIE. W artykule poruszono zagadnienie opracowania słownika terminologicznego. Określono zasady i opisano metodologiczne reguły konstruowania słownika systematyczne i wielopoziomowe odzwierciedlenie terminologii danej dziedziny jako jedności koncepcyjnej i kombinacji leksykograficznej opisu terminów. Opracowano makrostrukturalne i mikrostrukturalne parametry słownika terminologii z danej dziedziny.

Słowa kluczowe: terminologia z danej dziedziny, termin z danej dziedziny, makrostrukturalne i mikrostrukturalne parametry, słowik terminologiczny z danej dziedziny, zagadnienia metodologiczne układania słownika terminologicznego z danej dziedziny.

\section{METHODOLOGICAL PRINCIPLES OF BRANCH TERMINOLOGY DICTIONARY COMPILING}

\author{
TETIANA PETROVA \\ V. V. Dokuchaiev Kharkiv National Agrarian University, Kharkiv - Ukraine
}

ABSTRACT. The problems of compiling a branch terminology dictionary have been considered in the article. The methodological principles of the dictionary compiling - the systematic and multi-level reflection of the branch terminology as a conceptual unity and combining the lexicographic description of the branch terms have been determined and described. The macrostructural and microstructural parameters of the branch terminology dictionary have been developed.

Key words: branch terminology, branch term, macrostructural and microstructural parameters, branch terminology dictionary, methodological principles of making a branch terminology dictionary.

$\mathrm{T}$

ермінографічні праці відіграють важливу роль у збереженні та передаванні наукової термінології від покоління до покоління. Українська термінологічна лексикографія постійно розвивається, поповнює видову класифікацію видань, удосконалює старі й розробляє нові принципи та методи репрезентування наукової лексики, збагачує різні галузі спеціальними словниками. Важливими завданнями новітньої термінологічної лексикографії є систематизування, упорядкування, уніфікування наукової лексики.

Стрімкий науково-технічний прогрес сприяє потужному розвиткові кожної сучасної наукової сфери знань, іiі розбудові й розгалуженню на підгалузі (вузь- 
кі галузі). Потреба всебічно й системно репрезентувати сучасну термінологічну лексику певної галузі як впорядковану єдність ії підгалузевих термінологій, а також відсутність словника меліорації зумовлюють актуальність створення нового типу галузевого словника й розроблення методологічних засад його укладання. В українському мовознавстві теоретичні засади термінографії розробляють В. Дубічинський ${ }^{1}$, О. Іванова ${ }^{2}$, М. Комова $^{3}$, Л. Полюга ${ }^{4}$ Л. Симоненко $^{5}$, Л. Туровська ${ }^{6}$ та інші. „Об’ єктом термінологічної лексикографії є галузевий словник, предметом - вироблення методології і конкретних прийомів укладання термінологічних словників різних типів"”.

Галузевий термінологічний словник комбінованого типу покликаний дати читачеві комплексні відомості про сучасний стан різних національних галузевих терміносистем, а також систематизувати, нормалізувати та стандартизувати відповідні термінології, а тим самим сприяти подальшому розвиткові спеціальної лексики української літературної мови.

Створення галузевого термінологічного словника — це складний і тривалий процес, що проходить кілька взаємопов' язаних етапiв: 1) визначення типу словника і його особливостей; 2) формування макроструктури (загальної побудови) словника; 3) створення реєстру галузевих термінів; 4) розроблення параметрів мікроструктури (термінологічної статті) словника; 5) побудова дефініції понять; 6) установлення системних відношень між поняттями “всередині” підгалузі та між поняттями окремих підгалузей.

Методологічні принципи укладання галузевого термінологічного словни$\kappa \boldsymbol{a}$ - це комплекс принципів, способів репрезентування певної галузевої терміносистеми. Це методологічна основа, на яку спирається термінограф. Виділяємо такі методологічні принципи укладання галузевого термінологічного словника:

а) принциип системності й різнорівневості відображення поняттєво-термінологічного матеріалу галузі як впорядкованої єдності;

б) принцип комбінованості лексикографічного опису терміна як одиниці галузевої терміносистеми.

Під час лексикографічного опису галузевої терміносистеми перед укладачем словника постає низка проблем різного рівня: 1) визначення макроструктури словника; 2) репрезентування ієрархічної розгалуженості фахової лексики; 3) формування реєстру словника, виділення критеріїв відбирання терміноодиниць; 4) наповнення мікроструктури словника: вибір складників терміностатті; відображення системних відношень між поняттями, що формують терміносемантичні групи різних підгалузевих терміносистем; опис епідигматичних зв'язків.

${ }^{1}$ В. Дубічинський, Лексикографія, Харків, 2012.

2 О. Іванова, Зміст та структура поняття “термінологічна лексикографія", [в:] „Українська термінологія і сучасність”, Київ 2007, вип. VII, с. 332.

${ }^{3}$ М. Комова, Українське термінологічне словникарство, [в:] „Українська термінологія і сучасність”, Київ 2003, вип. VIII, с. 289-292.

${ }^{4}$ Л. Пол юг а, Проблематика прочесів творення термінологічних словників, [в:] „Наук. записки Терноп. нац. пед. ун-ту. Серія «Мовознавство»”, Тернопіль 2007, с. 255-265.

5 Л. Симоненко, Методологічні засади створення словника біологічної термінології, [в:] „Українське мовознавство”, Київ 2008, вип. 38, с. 155-159.

6 Л. Туровська, Сучасний етап розвитку української термінографії, [в:] Система і структура східнослов'янських мов, Київ 2006, с. 168-173.

7 О. І в ан о ва, Зміст та структура поняття “термінологічна лексикографія”..., с. 332. 
На сьогодні в сучасній українській термінографії є праця ${ }^{8}$, присвячена теоpiї розробляння принципів і засад укладання вузькогалузевого словника комбінованого типу з фітомеліорації. Поняття “комбінований словник” можна розуміти двояко: у вузькому значенні - видання, у якому поєднано параметри опису мовних одиниць у лінгвістичних словниках різних типів; у широкому - видання, у якому поєднано параметри й принципи репрезентування мовних одиниць у власне лінгвістичних та енциклопедичних словниках. У зазначеній монографії поняття “комбінований словник вузькогалузевої термінології (фітомеліоративної)" використано на позначення словника, у якому поєднано параметри енциклопедичного та лінгвістичних (акцентного, антонімів, синонімів, орфографічного, тлумачного) словників .

Принцип системності й різнорівневості відображсення поняттсвотермінологічного матеріалу галузі як цілісної сдності передбачає використання структурно-семантичного, тематичного, системного, дефінітивного параметрів. Словник галузевої термінології комбінованого типу репрезентує поняттєво-термінологічний апарат галузі як мегасистему, утворену сукупність макросистем - підгалузей, кожна з яких, відповідно, поділяється на мікросистеми.

Термінологія меліорації - одна 3 найдавніших і водночас сучасних українських терміносистем. Поняттєвий апарат цієї науково-прикладної дисципліни, сформований на межі кількох наук. Єдиної класифікації меліорацій на сьогодні не існує. Дослідники називають від 3 до 80 видів меліорацій ${ }^{10}$. Залежно від впливу на грунт і рослини існують такі види меліорації: гідромеліорація, земельна, кліматична, хімічна, фітомеліорація та інші. Галузеву терміносистему меліорація формують термінологічні системи іiі підгалузей з єдиним об'єктом впливу (грунт) та різними засобами впливу (вода, техніка, хімічні речовини, трав'яні й деревно-чагарникові рослини та інші). Отже, сучасна українська меліоративна лексика - розвинена термінологічна система, особливостями якої є: неоднорідність складу; внутрішня ії розгалуженість - наявність вузькогалузевих підсистем; перетин поняттєвих полів і повторювання терміно-семантичних груп $^{11}$ у мікрополях, спричинені наявністю системних зв'язків між спеціальними одиницями терміносистем.

Тип розроблюваного словника зумовлює його загальну побудову - макроструктуру. Диференційованість галузі, наявність значної кількості підгалузей меліорації, а відповідно, і їхніх підсистем, визначають принципи організування й розміщення спеціального лексичного матеріалу.

Параметричну систему макроструктури галузевого словника комбінованого типу формують такі складники: передмова, інструкція з користування, список скорочень, джерела, абетковий покажчик за підгалузями знань. Із-поміж перерахованих параметрів найважливішим є абетковий покажчик, що репрезентує поняття меліорації за підгалузями знань, зокрема водну, земельну, кліматичну, хімічну меліорації, фітомеліорацію та ін.

Під час складання реєстру термінологічного словника перед упорядниками постає головна проблема: які саме терміноодиниці необхідно подавати

${ }^{8}$ Т. Петрова, Фітомеліоративна термінологія сучасної украӥнської мови та ї̈ відображення в термінологічному словнику комбінованого типу, Харків 2018.

${ }^{9}$ Там само, с. 134-135.

${ }^{10}$ Г. Гл а ду н, Лісові меліорації агроландмафтів, Харків 2003, с. 93.

${ }^{11}$ Т. Петрова, Фітомеліоративна термінологія сучасної української мови та ї̈ відображення в термінологічному словнику комбінованого типу, Харків 2018, с. 22. 
в ньому. Для розв'язання цієї проблеми потрібно виробити критерії добирання реєстрових одиниць і вимоги до терміна. Технічний комітет стандартизування науково-технічної термінології (ТК СНТТ) розробив засади добирання українських реєстрових слів: 1) розвивати українську науково-технічну мову; 2) надавати перевагу питомому українському слову; 3 ) запозичати термін безпосередньо 3 мови-оригіналу; 4) засвоювати чужий термін за граматичними й правописними нормами української мови; 5) дотримуватися розподілу віддієслівних іменників за дією, подією й наслідком; 6) надавати перевагу українським дієслівним формам ${ }^{12}$. Уважаємо, що зазначені критерії доцільно комплексно використовувати й під час відбирання термінологічних одиниць до реєстру галузевого термінологічного словника.

Реєстр галузевого термінологічного словника меліорації формують такі одиниці:

1) вузькогалузеві терміни, що належать лише до певної меліоративної підгалузі, напр.: кліматичної - зона клімату, кліматоп, коефіиієнт зміни швидкості вітру; фітомеліорації - живопліт, залісення, лісорозведення; хімічної меліорації - ксенобіотики, опріснення, хімічна рівновага, глинування та ін.;

2) спеціальні найменування, використовувані в усіх підгалузевих терміносистемах (що зумовлено наявністю єдиного об'єкта впливу — грунт, на який впливають різними засобами), зокрема: вода, трунт, земля, меліорація, місиевість та ін.;

3) загальнонаукові терміни, що входять до складу меліоративної лексики: зона, режим, шкала, фактор та ін.

Добираючи матеріал до термінологічного словника, „[...] варто керуватися основними вимогами до терміна: системність, стислість, прозорість семантики, наявність словотвірних можливостей, евфонія (милозвучність), відповідність лінгвістичним правилам і нормам української мови"'13. Проблему добирання спеціальної лексики до реєстру сучасної загальномовної тлумачної лексикографічної праці Л. Боярова розв'язує шляхом дотримання трьох критеріїв: 1) когнітивно-комунікативна значущість терміна: „[...] на сьогодні необхідно відмовитися від принципу «поширеності терміна» як визначального під час добирання спеціальних одиниць до загального тлумачного словника, а слід орієнтуватися на когнітивно-комунікативну значущість термінологічної назви"14; 2) нормативність терміна - „,...] укладачі сучасної лексикографії повинні орієнтуватися на нову нормативну базу словникової кодифікації, розроблену науковцями у 90-их роках XX століття - на початку XXI століття. Словники потрібно оновлювати після змін у самій мові та в оціненні ії засобів у мовному колективі”"15; 3) сучасність терміна:,, [...] спеціальну лексику слід фіксувати в словниках $[\ldots]$ саме в синхронії, тобто укладачам не варто подавати застарілі термінологічні значення чи терміни, які вийшли з ужитку"16. Уважаємо, що означені критерії $\epsilon$ виваженими й беззаперечними, тому їхнє дотримання забезпечить високу якість змістової основи термінографічного продукту.

${ }^{12}$ Порадник для укладачів фахових словників, [в:] Електронний pecypc: http://tc.terminology. lp.edu.ua/TK_vocab.htm\#Sect3 (24.12.2017).

${ }_{13}$ Л. Тур о в с ка, Термінологія $і$ мова спеціального призначення: зони перетину, [в:] „Термінологія документознавства та суміжних галузей знань”, Київ 2011, № 5, с. 33-38, [в:] Електронний ресурc: http://term-in.org/goods/15-1-1-1/category/id110/ (20.10.2017).

${ }^{14}$ Л. Бо я р о в а, Термінологічна лексика в загальномовному тлумачному словнику, [в:] „Лексикографічний бюлетень", Київ 2008, вип. 17, с. 17.

${ }^{15}$ Там само, с. 20.

${ }^{16}$ Там само, с. 20. 
Принци комбінованості лексикографічного опису терміна як одиниці галузевої терміносистеми. У галузевому словнику комбінованого типу параметричний склад базової структурної одиниці - термінологічної статmi, або мікроструктури, - формують заголовний термін, його лінгвістична характеристика, дефініція, енциклопедична інформація, системні відношення (гіперогіпонімія, антонімія, синонімія). Якщо зміст, способи й прийоми лінгвістичного опису заголовних термінів і у вузькогалузевому словнику комбінованого типу (далі ВГСКТ), і в галузевому словнику комбінованого типу (далі ГСКТ) не відрізняються, то обсяг дефініцій, вияв системних відношень між поняттями підгалузей та їхніх різновидів можуть бути відмінними й потребують ретельного їхнього відстеження. Напр., розглянемо розбіжності в репрезентуванні параметра “дефініція” поняття “десукція” у вузькогалузевому і в галузевому словниках:

\begin{tabular}{|c|c|}
\hline у ВГСКТ фітомеліорації & у ГСКТ меліорації \\
\hline $\begin{array}{l}\text { Десукція - поглинання грунтової } \\
\text { вологи кореневими системами дерев } \\
\text { та чагарників, що виникає в літній } \\
\text { період i призводить до посиленої } \\
\text { втрати грунтом доступної рослинам } \\
\text { вологи безпосередньо під лісовими } \\
\text { насадженнями. }\end{array}$ & $\begin{array}{l}\text { Десукція - }-1 . \quad \text { Процес } \\
\text { відсмоктування вологи з грунту коренями } \\
\text { рослин. 2. У рівнянні водного балансу } \\
\text { кількість води, яка відсмоктується } \\
\text { рослинами з грунту за той проміжок часу, } \\
\text { для якого складається баланс. }\end{array}$ \\
\hline
\end{tabular}

Мовний аналіз засвідчує, що дефініція галузевого поняття, на відміну від вузькогалузевого, містить певні відмінності, спричинені відображенням внутрішньосистемних епідигматичних (полісемічних) відношень - між термінами фітомеліорації та гідромеліорації.

Відстежуємо також розбіжності в кількісному наповненні параметра “гіперо-гіпонімія" під час опису поняття “рельєф” у ВГСКТ та ГСКТ:

\begin{tabular}{|c|c|}
\hline у ВГСКТ фітомеліорації & у ГСКТ меліорації \\
\hline $\begin{array}{l}\text { Рельєф } \\
\text { • антропогенний; } \\
\text { • піщаних земель; } \\
\text { •• барханний; } \\
\text { горбистий; } \\
\text { грядовий; } \\
\text { котловинний; } \\
\text { купчастий; } \\
\text { рівнинний; } \\
\text { терасовий; } \\
\text { • суші; } \\
\text { • техногенний; } \\
\text { • макрорельєф; протилежне } \\
\text { мікрорельєф; } \\
\text { • мезорельєф; } \\
\text { • мікрорельєф; протилежне } \\
\text { макрорельєф; } \\
\text { • нанорельєф }\end{array}$ & $\begin{array}{l}\text { Рельєф } \\
\text { • антропогенний; } \\
\text { • вирівняний; } \\
\text { • гірський; } \\
\text { • іригаційний; } \\
\text { • піщаних земель; } \\
\text { •• барханний; } \\
\text { горбистий; } \\
\text { грядовий; } \\
\text { котловинний; } \\
\text { купчастий; } \\
\text { рівнинний; } \\
\text { терасовий; } \\
\text { • розчленований; } \\
\text { • суші; } \\
\text { • техногенний; } \\
\text { • макрорельєф; протилежне } \\
\text { мікрорельєф; } \\
\text { • мезорельєф; } \\
\text { • мікрорельєф; протилежне } \\
\text { макрорельєф; } \\
\text { • нанорельєф. }\end{array}$ \\
\hline
\end{tabular}


Як бачимо, гіперонім рельєф отримує більшу кількість гіпонімів у мегатерміносистемі меліорації, ніж у макротерміносистемі фітомеліорації.

Для розроблюваного типу словника важливо відстежити й виявити здатність заголовного терміна вибудовувати системні відношення між вузькогалузевими одиницями. Так, у термінології фітомеліорації гіперонім вологість має гіпонім — повітря (вологість повітря). У терміносистемах гідромеліорації і меліорації грунтів значення цього гіпероніма звужують такі співгіпоніми: вологість - вологість мінеральних добрив, вологість трунту, вологість прилипання трунту, вологість розриву капілярних зв'язків, вологість сталого в'янення рослин. При цьому з-поміж названих гіпонім вологість трунту є гіперонімом наступного рівня ієрархії - вологість трунту абсолютна, вологість tрунту вагова, вологість трунту об 'ємна, вологість трунту відносна. Відповідно в ГСКТ меліорації терміностаття поняття "вологість" міститиме зведений опис родо-видових відношень: • стійкого в’янення рослин; • уповільнення росту рослин; $\bullet \sim$ мінеральних добрив; $\bullet \sim$ грунту; $\bullet \sim \sim$ абсолютна, $\sim \sim$ вагова, $\sim$ $\sim$ об'ємна, $\sim \sim$ відносна; $・ \sim$ прилипання грунту; $\bullet \sim$ розриву капілярних зв'язків, - в'янення рослин.

Вузькогалузеві терміни можуть вибудовувати родо-видові відношення лише між одиницями певної підгалузевої терміносистеми (напр. фітомеліорації, лісистість - мінімальна необхідна лісистість, полезахисна лісистість). Відповідно обов'язково слід їх навести на своєму місці в терміностатті реєстрового поняття "лісистість" у ГСКТ, а в абетковому покажчику за підгалузями знань - подати його в переліку спеціальних найменувань фітомеліорації, чим і визначимо його місце в мегатерміносистемі.

До деяких термінів, що потребують обчислень, у зоні дефініції розміщуємо енциклопедичну інформацію (числові формули), напр.: Гідротермічний коефіціснт - відношення щомісячної кількості опадів за вегетаційний період до смуги температур за такий самий період. Обчислюють за такою формулою:

$$
\Gamma \mathrm{TK}=\frac{10 \mathrm{R}}{\sum \mathrm{t}},
$$

де $10 \mathrm{R}$ - кількість опадів; $\sum \mathrm{t}$ - сума температур за цей самий період часу.

Отже, головними в репрезентуванні галузевих термінів у комбінованому словнику є принцип системності й різнорівневості відображення поняттєвотермінологічного матеріалу галузі як цілісної єдності, принцип комбінованості лексикографічного опису терміна як одиниці галузевої терміносистеми. Комбінований галузевий словник меліоративної термінології дає змогу розв'язати низку методологічних проблем теоретичної і практичної термінографії: 1) з'ясувати специфіку системної організації сучасної розвиненої галузевої термінології; 2) уніфікувати критерії відбирання реєстрових терміноодиниць; 3) виробити єдині способи репрезентування системних відношень у галузевому словнику. Цей словник розглядаємо як важливий науковий довідник із меліорції.

\section{Список використаної літератури}

Боярова Л., Термінологічна лексика в загальномовному тлумачному словнику, [в:] „Лексикографічний бюлетень”, Київ 2008, вип. 17, с. 13-23.

Гладун Г., Лісові меліоращії агроландмафтів, Харків 2003.

Дубічинський В., Лексикографія, Харків 2012.

Іванова О., Зміст та структура поняття “термінологічна лексикографія”, [в:] „Українська термінологія і сучасність”, Київ 2007, вип. VII, с. 331-333. 
Комова М., Українське термінологічне словникарство, [в:] „Українська термінологія і сучасність", Київ 2003, Вип. VIII, с. 289-292.

Петрова Т., Фітомеліоративна термінологія сучасної украӥнської мови та ії відображення в термінологічному словнику комбінованого типу, Харків 2018.

Полюга Л., Проблематика процесів творення термінологічних словників, [в:] „Наук. записки Терноп. нац. пед. ун-ту. Серія «Мовознавство»”, Тернопіль 2007, с. 255-265.

Порадник для укладачів фахових словників, [в:] Електронний ресурс: http://tc.terminology. lp.edu.ua/TK_vocab.htm\#Sect3 (24.12.2017).

Симоненко Л., Методологічні засади створення словника біологічної термінологї, [в:] „Українське мовознавство”, Київ 2008, Вип. 38, с. 155-159.

Туровська Л., Сучасний етап розвитку української термінографії, [в:] Система і структура східнослов'янських мов, Київ 2006, с. 168-173.

Туровська Л., Термінологія $і$ мова спеціального призначення: зони перетину, [в:] Термінологія документознавства та суміжних галузей знань, Київ 2011, № 5, с. 33-38, [в:] Електронний ресурс: http://term-in.org/goods/15-1-1-1/category/id110/ (20.10.2017).

\section{Spysok vykorystanoi literatury [References]}

Boiarova L., Terminolohichna leksyka v zahalnomovnomu tlumachnomu slovnyku [Terminological Lexis in Explanatory Dictionary], [v:] „Leksykohrafichnyi biulleten”, Kyiv 2008, vyp. 17 , s. $13-23$.

Hladun H., Lisovi melioratsii ahrolandshaftiv [Forest Meliorations of Agricultural Landscapes], Kharkiv 2003.

Dubichynskyi V., Leksykohrafiia [Lexicography], Kharkiv 2012.

Ivanova O., Zmist ta struktura poniattia "terminolohichna leksykohrafiia" [Content and Structure of Notion "Terminological Lexicography»], [v:] „Ukrainska terminolohiia i suchasnist", Kyiv 2007, vyp. VII, s. 331-333.

Komova M., Ukrainske terminolohichne slovnykarstvo [Ukrainian Terminological Dictionary Compiling], [v:] „Ukrainska terminolohiia i suchasnist”, Kyiv 2003, vyp. VIII, s. $289-292$.

Petrova T., Fitomelioratyvna terminolohiia suchasnoi ukrainskoi movy ta yii vidobrazhennia $v$ terminolohichnomu slovnyku kombinovanoho typu [Phitomeliorative Terminology of Modern Ukrainian and its Reflection in Terminological Dictionary of Combined Type], Kharkiv 2018.

Poliuha L., Problematyka protsesiv tvorennia terminolohichnykh slovnykiv [Problem of Terminological Dictionaries Formation Processes], [v:] „Nauk. zapysky Ternop. nats. ped. un-tu. Seriia «Movoznavstvo»", Ternopil 2007, s. 255-265.

Poradnyk dlia ukladachiv fakhovykh slovnykiv [Recommendations for Terminological Dictionaries Compilers], [v:] Elektronnyi resurs: http://tc.terminology.lp.edu.ua/TK_vocab. htm\#Sect3 (24.12.2017).

Symonenko L., Metodolohichni zasady stvorennia slovnyka biolohichnoi terminolohii [Methodological Fundamentals of Biological Terminology Dictionary Compiling], [v:] „Ukrainske movoznavstvo”, Kyiv 2008, vyp. 38, s. 155-159.

Turovska L., Suchasnyi etap rozvytku ukrainskoi terminohrafii [Modern Stage of Ukrainian Terminography Development], [v:] Systema i struktura skhidnoslovianskykh mov, Kyiv 2006, s. 168-173.

Turovska L., Terminolohiia $i$ mova spetsialnoho pryznachennia: zony peretynu [Terminology and Language for Special Purposes: Zones of Crossings], [v:] „Terminolohiia dokumentoznavstva ta sumizhnykh haluzei znan”, Kyiv 2011, № 5, s. 33-38, [v:] Elektronnyi resurs: http://term-in.org/goods/15-1-1-1/category/id110/ (20.10.2017). 